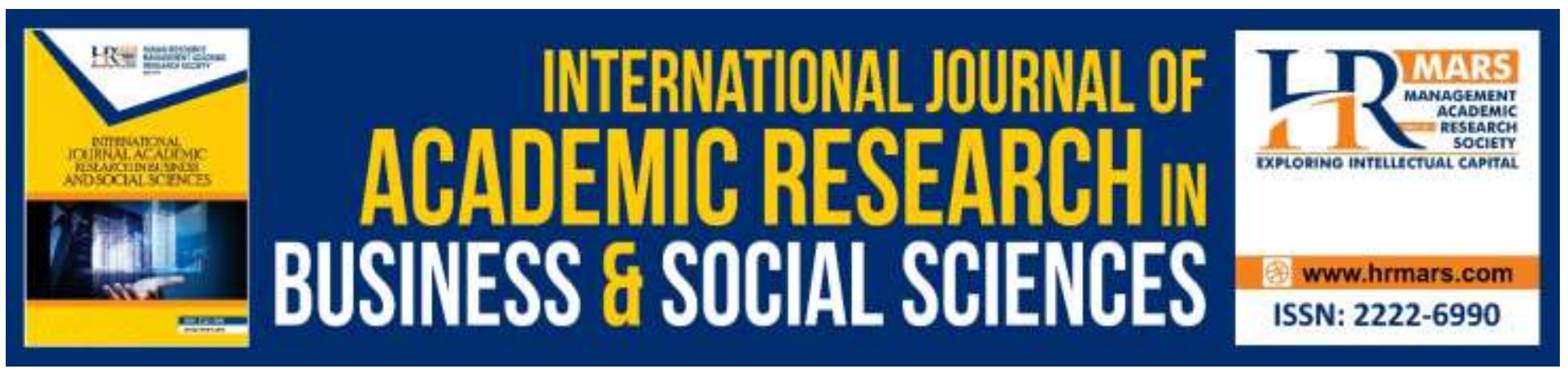

\title{
Reader's Theatre: To Enhance Reading Amongst Pre-School Readers
}

\section{Syarul Azlina Bt Dato' Haji Sikandar, En Zolkipli Bin Haji Abdullah, Sumathi Maniam Raj}

To Link this Article: http://dx.doi.org/10.6007/IJARBSS/v8-i7/4319

DOI: $10.6007 /$ IJARBSS/v8-i7/4319

Received: 24 May 2018, Revised: 19 June 2018, Accepted: 29 June 2018

Published Online: 08 July 2018

In-Text Citation: (Sikandar, Abdullah, \& Raj, 2018)

To Cite this Article: Sikandar, S. A. B. D. H., Abdullah, E. Z. B. H., \& Raj, S. M. (2018). Reader's Theatre: To Enhance Reading Amongst Pre-School Readers. International Journal of Academic Research in Business and Social Sciences, 8(7), 1-7.

Copyright: (C) 2018 The Author(s)

Published by Human Resource Management Academic Research Society (www.hrmars.com)

This article is published under the Creative Commons Attribution (CC BY 4.0) license. Anyone may reproduce, distribute, translate and create derivative works of this article (for both commercial and non-commercial purposes), subject to full attribution to the original publication and authors. The full terms of this license may be seen at: http://creativecommons.org/licences/by/4.0/legalcode

\section{Vol. 8, No. 7, July 2018, Pg. 1 - 7}

Full Terms \& Conditions of access and use can be found at http://hrmars.com/index.php/pages/detail/publication-ethics 


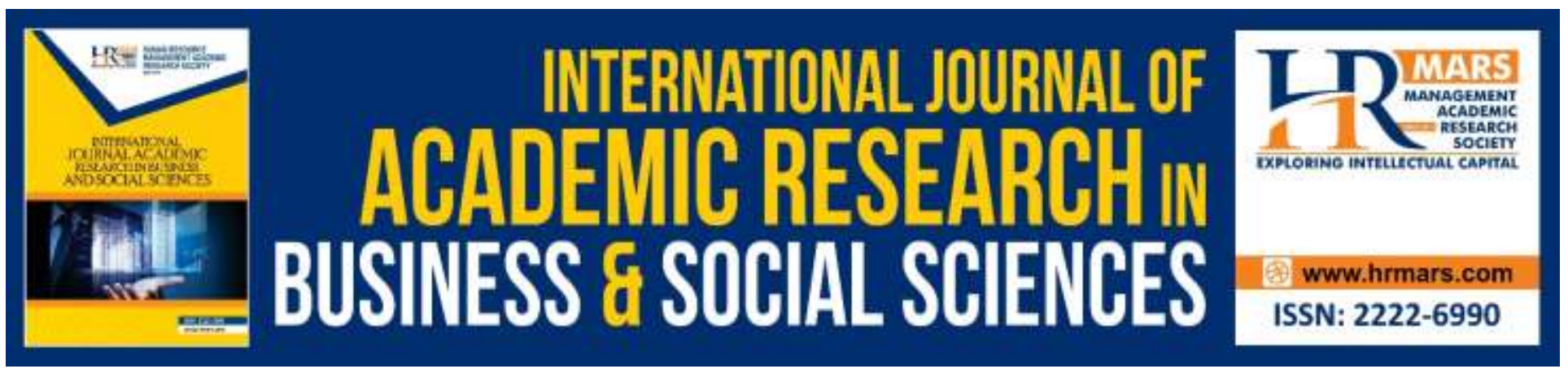

\title{
Reader's Theatre: To Enhance Reading Amongst Pre- School Readers
}

\author{
Syarul Azlina Bt Dato' Haji Sikandar, En Zolkipli Bin Haji Abdullah, \\ Sumathi Maniam Raj \\ Faculty of Music and Performing Arts, Sultan Idris Education University, Malaysia
}

\begin{abstract}
This article presents a study of the use of Reader's Theatre in English lessons with groups of 5 year old preschool children. Reader's Theatre has been implemented to investigate its effectiveness towards improving fluency and comprehension skills of preschool children in Malaysia. Data was collected from 6 preschool children in the District of Shah Alam, Selangor. The study is based on the teacher's logs, interviews with the teacher, and lesson observations. Most of the children struggle with English as their second language and are struggling readers. However, the majority of the children experienced Reader's Theatre as both enjoyable and educational. The experience had a positive effect on their confidence and motivation to read. It also helped to improve their reading fluency and accuracy for example pronunciation, and facilitated growth in vocabulary. The experience of practising and performing as a group was especially satisfying and motivating for the children involved. Therefore, Reader's Theatre instruction is beneficial to increase fluency skill for the preschool children in Malaysia and thus recommended as part of literacy enhancement in the preschool classroom.
\end{abstract}

Keywords: Reader's Theatre, Pre-schoolers, English language.

\section{Introduction}

The study aims to show that Reader's Theatre will develop the students' reading fluency and comprehension. Abdul Rasid Jamian (2011), states that the school's complex curriculum system and the insensitivity to the needs of the students with different reading ability as the reasons to the hindrance of reading and comprehension. Teachers are inclined to complete the syllabus rather than focus on the individual child's learning abilities or the lack of it. Another reason attributed to the matter in hand is the implementation of the reading curriculum itself. The curriculum places more emphasis on the children acquiring the phonetics skills. It stipulates that a series of phonetics assessments to be carried out throughout the year, which does not include the assessment of fluency or comprehension - the components necessary to achieve the ability to read and comprehend. Currently, it is assumed that the ability to read with comprehension is achieved if a child is able to spell and read the word correctly. In view of this, lack of fluency in reading is also a key factor which attributes to the inability to comprehend the text that affects the overall reading development. One 
of the methods suggested for a preschool classroom is to incorporate Reader's Theatre instructions in the teaching of reading. It is believed that through Reader's Theatre, the children's motivation and interest in reading could be achieved. The objectives of this study are firstly to identify the importance of Reader's Theatre on 5 year old preschool children through the teachers' perspective and to examine the effects of Reader's Theatre on 5 year old preschool children's fluency and comprehension skills.

\section{Background}

This article presents a study of the use of Reader's Theatre in English lessons with groups of 5 year old preschool children in Tadika Permata PKPS. This is one of a drama technique involving a group of children. This method gives children the opportunity to play with less equipment, props, settings, costumes and memory. Reader's Theatre, is a style of theatre in which the actors do not memorize their lines. Actors use only vocal expression to help the audience understand the story rather than visual storytelling such as sets, costumes, intricate blocking, and movement. It aims to enable audience to have easy comprehension, appreciate and feel as if the story is happening in front of their eyes. These are some of the purposes of Reader's Theatre :

- Foster interest in reading and training children mastered oral and verbal skills voice intonation in reading

- Increase the power of thought to be smart and creative.

- Building self confidence

- Improve cooperation

- Discipline children

- Discipline the thinking process of children

- Stimulate and attract children

- Motivate and create atmosphere conducive and fun in activity teaching and learning

- Reveal talent and talent acting which is in children

- Provide opportunities for more children to get involved.

Flynn (2004), stated that proficient readers are those who are able to read a text with comprehension and fluency. Some struggling readers do not grasp these skills as most struggling readers are unable to read the texts fluently as they are unable to spell the words spontaneously. The struggling readers do not grasp these skills as most struggling readers are unable to read the texts fluently as they are unable to spell the words spontaneously. Readers who continue to experience such difficulties in reading tend to avoid participating in reading activities. This avoidance will result in the lack of reading practice which is greatly needed by struggling readers (Caudill-Hansen, 2009). Many studies have proven that fluency skills can be enhanced through repeated reading (Cooper \& Kiger, 2009). Therefore, an interesting technique should be employed to encourage children to read repeatedly as repetition will enhance their reading skills.

There are five components of reading that are crucial for the children to acquire which are phonemic awareness, phonetics, fluency, vocabulary, and comprehension. In Malaysia, less attention is given to the mastery of fluency and comprehension in the preschool classrooms as most methods used to teach reading are focused on acquiring phonetics skills compared to other components. In view of the fact that the combination of the five components are crucial in determining whether a child is a proficient or a struggling reader, it is necessary to create a complete reading program that includes all the components in our classroom reading curriculum. 


\section{Reader's Theatre: Fluency and comprehension}

Johnson (2011) also conducted a study that focused on fluency and comprehension. He collected pretest and post-test data through quasi-experimental method. The study involved 44 Second Grade students and two teachers at the suburban Southeastern Primary School. Two of the students from the experimental group were struggling readers. Reader's Theatre was carried out daily with the experimental group for 9 weeks. During the intervention period, the children were introduced to scripts that were suitable for their reading level ranging from first grade to third grade. Each group involved four to six students working together for 10-20 minutes. During the first four days of practice, the teachers guided the children in reading fluency and comprehension. At the end of the Reader's Theatre performance, consistent positive feedback was received from the teachers. The analysis showed that there was a significant difference in fluency for the experimental group. However, the data collected for comprehension was not statistically significant. In conclusion, Reader's Theatre managed to promote social change among the students who were involved in this study.. It was also proven that Reader's Theatre is an authentic technique to engage readers in meaningful activities and is able to increase the children's reading fluency. The research design used qualitative method. This method was chosen as the study examined the effect of using Reader's Theatre on fluency, comprehension and social emotional development of the preschool children. The selected schools were located in the district of Shah Alam, Selangor. The selection of schools in the same area was intentional so as to reduce the effects of external variables that could influence the result of this study.

The selected sample involved 6 children aged 5 years old. Researcher conducted the research for 4 weeks in order to observe the effectiveness of Reader's Theatre as a teaching strategy to enhance children' fluency and comprehension skills. The researcher chose the samples based on their range of English ability. The children sit in semicircle position and the researcher chose scripts with strong dialogue. There searcher allowed the children to feel comfortable and get into performance mode. Here opportunities for children to practice are provided. Children do not memorize their parts; they always read from their scripts. The children work in small groups, not with the whole class. The researcher also provides instructional support for new vocabulary and for the understanding of different characters.

\section{The teacher's log}

After each group had completed a Reader's Theatre cycle, the teacher evaluated the process with the children in plenary, eliciting their reactions to the experience and writing these in a log. In addition, the teacher kept a log of his own reflections on the experiences, both during the process of working with Reader's Theatre.

\section{Lesson observations}

During the Reader's Theatre activity, the researcher noted the children' level of concentration, their ability to articulate the text and the extent to which they seemed to enjoy the experience. During the session, the researcher noted the degree to which the children were motivated and concentrated while working with the text, how they interacted with each other and how they interacted with the teacher. 


\section{Interviews with the teacher}

The teacher was interviewed on five occasions using semi-structured interviews that allowed for both pre-planned questions to be asked but also for additional questions to be posed as the interviews evolved. The interview was conducted and the answer elicited involved the teacher's reasons for trying the method out, the kinds of texts that might be suitable and his expectations. The next three interviews were conducted following the classroom observations. Questions were askedabout, for example, how the children had responded to working with Reader's Theatre, what the teacher's role had been, and how the children had benefited from the experience.

\section{Findings}

\section{What are the importance of Reader's Theatre on 5 years old preschool children based on the teachers' perspective?}

Reader's Theatre is a new century learning strategy to attract children in the classroom. Chalk and talk learning has become less attractive to the children. The results of teachers' interview show that kids now need something new that can raise curiosity, want to learn more. The teacher argues that Reader's Theatre attracts $98 \%$ of children's focus during the teaching and learning process. They prefer to do their own with the guidance of the teacher rather than just one-way learning.

In addition, Reader's Theatre increases the active involvement of children in the classroom. This is because it involves two-way learning that requires not only a teacher to teach. This gives advantages to children's communication. Children are more likely to talk to other children where they can increase confidence and social value in themselves. This can be proved when a child was once a passive, did not want to associate with other children. When this activity is conducted, the child is more active and likes to ask questions about what they are going through. This is a positive impact in classroom learning activities.

Finally, teachers think Reader's Theatre can provide a fun learning environment. In the past,there is a number of children do not want to go to preschool because they are afraid of the teachers and their own friends. With such activities, children forget the negative things happening in preschool. This can be seen based on their face reaction when doing this activity. It can be identified when there were a number of children who would cry when go to preschool, now the number of crying children while go to preschool decreases. This shows a positive impact on the socio-psychosis of children.

\section{What are the effects of Reader's Theatre on 5 years old preschool children's fluency and comprehension skills?}

The result of the teacher's log and lesson observation shows that Reader's theatre provides an authentic purpose for repeated readings. Children need repeated practice of the readings in order to prepare for being in front of an audience. Additionally, reader's theatre provides a social aspect for children to interact with one another. These factors keep children engaged and interested in the lesson. Reader's theatre improves comprehension as well as fluency, because in order for a reader to portray the correct emotions he or she must understand the characters background and emotions, as well as the plot of the story. The purpose for reading with expression is so that the audience can visualize the story. Reader's theatre can be used to connect oral reading, drama, important literature. Children become invested on their readings, because they can add their thoughts and emotions into the readings. Not only does this help engage children, but it also improves children' comprehension. In order to effectively read passages children must consider plot, setting, character motives, and 
INTERNATIONAL JOURNAL OF ACADEMIC RESEARCH IN BUSINESS AND SOCIAL SCIENCES

Vol. 8, No. 7, June 2018, E-ISSN: 2222-6990 @ 2018 HRMARS

character relationships. These aspects create a deeper understanding of the text. Reader's theatre can be used with a variety of texts. Fiction is often used within scripts, but non-fiction texts can be used as well. Additionally, content area readings can be turned into Reader's Theatre scripts. Content area Reader's Theatre scripts are especially useful for preschool aged students. Children at this age are beginning to read to learn as opposed to learning to read. Using content area readings for scripts is a form of curriculum based reader's theatre. Curriculum based Reader's Theatre takes curriculum content and forms it into scripts. Furthermore, it will help children better understand content area vocabulary.

\section{Conclusion}

As a researcher, it was amazing to see the children's desire to entertain audiences with their prosodic reading. Because of their motivation to practice, refine, and perform texts, an academic avenue was created to increase reading fluency, read multiple text types, and include every child striving or thriving. It was relatively easy to implement, fun, and instilled confidence in the young readers. Reader's Theatre had a profound positive effect on all readers and gave an opportunity for struggling readers to read fearlessly in the limelight. Regardless of the compensatory strategies used in practice, their performance reflected proficient reading that was adequately paced, prosodic, confident, accurate, and filled with meaning and enthusiasm. Every performance day, the struggling readers were in step and were virtually indiscernible from the rest of the class. The teachers should be mindful of slower readers because they will ultimately read less and their overall growth in reading will be restricted. However, Reader's Theatre led to a doubling of the mean reading rate, thus being advantageous in that children had the ability and opportunity to read more. The variations of scripts necessarily encouraged wider reading. All students whether high, low, or medium reading abilities, were given an opportunity to read more and across genres. In conjunction with improved prosody and increased reading rate, comprehension also improved.

\section{References}

Abdul, R. J. (2011). Permasalahan kemahiran membaca dan menulis bahasa melayu. Jurnal Pendidikan Bahasa Melayu.Vol.1, Bil. 1(Mei 2011): 1-12.

Flynn, R. M. (2004). Curriculum-based readers theatre: setting the stage for reading and retention. The Reading Teacher, 58(4), 360-365.

Caudill-Hansen, K. J. (2009). Readers' theater as a strategy to increase comprehension and fluency in sixth grade students. doctoral dissertation. Walden University.

Chan, A., \& Chan, S. (2009).Promoting assessment for learning through Readers' Theatre. IATEFL Young Learner and Teenage Special Interest Group, 2(09), 40-50.

Cooper, J., \& Kiger, N. (2006). Literacy: helping children construct meaning. Boston: Houghton Mifflin.

Johnson, D. D. (2011). The effect of a readers theater instructional intervention on second grade students' reading fluency and comprehension skills. Doctoral

Peebles, J. L. (2007). Incorporating movement with fluency instruction: A motivation for struggling readers. The Reading Teacher, 60(6), $578-581$.

Rinehart, S. D. (1999). "Don't think for a minute that I'm getting up there": Opportunities for Readers' theatre in a tutorial for children with reading problems. Reading Psychology, 20,7189.

Samuels, S. J. (1997). The method of repeated readings. The Reading Teacher, 50, 376 -381. 
INTERNATIONAL JOURNAL OF ACADEMIC RESEARCH IN BUSINESS AND SOCIAL SCIENCES Vol. 8, No. 7, June 2018, E-ISSN: 2222-6990 @ 2018 HRMARS

Tyler, B., \& Charard, D. J. (2000). Using readers theatre to foster fluency in struggling readers: a twist on the repeated reading strategy. reading \& writing quarterly, 16(2),163-168.

Uthman, L. E. (2002). Readers' theatre: an approach to reading with more than a touch of drama. Teaching prek-8, 32(6), 56-57. 